\title{
Evaluation of two methods of estrus synchronization of cattle in Chad
}

\author{
Vounparet Zeuh ${ }^{1^{*}}$, Mopate Logtene Youssouf ${ }^{2}$, Nadjilem Dingamtar $^{3}$, Djonret Dezoumbe $^{2}$ \\ ${ }^{1}$ Livestock Polytechnic Institute of Moussoro, Moussoro, Chad; ${ }^{*}$ Corresponding Author: vounzeuh@yahoo.fr \\ ${ }^{2}$ Zootechnical and Veterinary Research Laboratory, N’Djamena, Chad \\ ${ }^{3}$ Faculty of Exact and Applied Sciences, University of N'Djamena, N'Djamena, Chad
}

Received 17 October 2013; revised 19 November 2013; accepted 1 December 2013

Copyright (c) 2014 Vounparet Zeuh et al. This is an open access article distributed under the Creative Commons Attribution License, which permits unrestricted use, distribution, and reproduction in any medium, provided the original work is properly cited. In accordance of the Creative Commons Attribution License all Copyrights (c) 2014 are reserved for SCIRP and the owner of the intellectual property Vounparet Zeuh et al. All Copyright (C) 2014 are guarded by law and by SCIRP as a guardian.

\section{ABSTRACT}

The results of an artificial insemination experiment carried out in the suburban area of N'Djamena are here reported. Two methods of synchronization (Norgestomet combination/estradiol/PGF $2 \alpha$ IPMSG and PGF $_{2 \alpha}$ only) were used with Chadian zebu and crossed breeds in 2007 and 2008. Females were inseminated after induction of estrus with semen of French Normand breed. The fertility rate was low with $\mathrm{PGF}_{2 \alpha}$ (29.41\%). The results obtained with the combination of several hormones were better (66.66\%). The survival rates of crossbreeds were particularly low, $40 \%$ in 2007 and $33.33 \%$ in 2008, mainly due to the traditional management of the herd and the lack of technical support. The insemination cost of a cow was 39,550 F CFA in 2007 with $\mathrm{PGF}_{2 \alpha}$ and 59,200 F CFA in 2008 with the method consisting of combining of four hormones. The cost of producing a calf in those two years was very high, 134,470 F CFA in 2007 and 118,400 F CFA in 2008.

\section{KEYWORDS} Cattle; Estrus Synchronization; Pregnancy; Cost;
Chad

\section{INTRODUCTION}

Artificial insemination is elsewhere quite an old and known practice that it is not necessary to recall the principles and the uses to be made of. Yet this essential management tool of reproduction, particularly in breeding programs, has not yet found its place in Chad. There are many reasons for this, but one has to look into the system of Chadian livestock production which is rather extensive (about 80\%) in the form of nomadism and transhumance. The first attempt to improve domestic ruminants in the $50 \mathrm{~s}$ has occurred through importation of live breeding animals. The improved suburban livestock raising around large urban centers is not well developed in Chad compared to other parts of Africa. However, the evolution is beginning with the increase in number of farms along the Chari and Logone, two rivers alone N'Djamena. These structures put in place by a few wealthy people need more and more modern farming techniques based on models of neighboring countries. Thus in 2006, a private farm in the suburban area of N'Djamena has requested technical support for crossing Chadian cattle breeds with a French dairy breed using the technique of artificial insemination. The primary objective of the breeder was not milk production as he said, but rather to be in the elite field at the example of what he has seen elsewhere in the other countries.

Cost management of artificial insemination programs includes reducing costs resulting failures of the female to become pregnant after artificial insemination and costs incurred for the detection of estrus [1,2]. One goal with any insemination program is to attain high pregnancy rates at the lowest possible cost [3].

Costs resulting from the use of the two techniques of estrus synchronization and constraints are discussed in this article.

\section{MATERIALS AND METHODS}

\subsection{Animals}

At the end of 2008, the breeding herd consisted of cows from different breeds. The experimental group consisted of 160 females of Arab zebu, 60 females of 
M'bororo zebu, 10 females of Kuri and 10 females crossbred between Kuri and Arab. They were kept throughout the year on natural pasture and received a mineral supplementation (Salt Lick) in addition to a protein meal (cottonseed cake) during the hot dry season months. Of the 240 females used for reproduction, 170 were synchronized by a method of double injection of prostaglandin and inseminated in 2007 and 120 by a method of four hormones combination in 2008.

\subsection{Treatments and Products Used}

Artificial insemination is a method of fecundation assisted by placing sperm in the female genital tract. It is done on natural or artificially induced heat by biotechnological methods (induction and/or synchronization of estrus).

Several methods of estrus induction in cattle exist. Two of which were used in this study as reported in Table 1:

1) The method of prostaglandins: On cycled females, the action of prostaglandins to lyse corpora lutea can, after two injections at 11 days interval, induce 95 percent of heats. The first injection takes place at any time of the cycle and the second 11 days later to be sure to act on cows that were between the first and fifth day or between the 16th and 20th day of the cycle, two periods during which prostaglandin does not affect the corpus luteum. But, on suckling cows and especially zebu with extremely prolonged postpartum anestrus (so no yellow body), the action of prostaglandin has little effect. On the flow diagram for treatment of our first trial (Table 1), we used Luprostiol $(7.5 \mathrm{mg})$ a synthetic analogue of prostaglandin $\mathrm{F}_{2}$ alpha $\left(\mathrm{PGF}_{2 \alpha}\right)$.

2) Combination method using Norgestomet /Estradiol /PGF2 $\alpha$ /PMSG: This is the method recommended by INRA (National Institute for Agronomic Research, France) which associates estradiol which destroys any possible body and progesterone which inhibits the secretion of pituitary gonadotropins (FSH and LH). The follicle-stimulating effects of serum gonadotropin or PMSG (Pregnant Mare Serum Gonadotropin) and the luteolytic $\mathrm{PGF}_{2 \alpha}$ make it possible to induce and synchronize a short sexual cycle. Treatment with implants detailed in Table 1 was established for the combination method.
The implant placed under the skin to the outer surface of the ear contains $3 \mathrm{mg}$ of norgestomet (17 $\alpha \beta$-acetoxy11-methyl-19-norpreg-4-en-3, 20 dione), which will be released at a rate of $0.20 \mathrm{mg}$ per day during the 10 days of the trial. The Norgestomet provided by the implant blocks the release of gonadotropin hormones from the pituitary gland. On withdrawal, the blockage suddenly stops and females having received the indicated amount show then, and synchronously, a follicular phase, which leads to heat and ovulation. An injection of serum gonadotropin at the same time completes or replaces the full discharge of endogenous gonadotropic hormone.

\subsection{Insemination}

The breed chosen by the farmer to improve the level of his herd is the French Normand. It is a mixed breed, that is to say, it serves both for milk and meat productions. The semen is imported in the form of thin flakes of $0.25 \mathrm{ml}$ frozen in liquid nitrogen. These are the semen of two sires (Fukrain and Gerfaut) that have been imported for the two operations. Inseminations take place on the $72^{\text {nd }}$ and $96^{\text {th }}$ hours after the second injection of PGF2 $\alpha$ for the first method and on the $48^{\text {th }}$ and $72^{\text {nd }}$ hour after removal of the implant for the second method.

The grouping of calving was planned over two seasons: the beginning of the rainy season in 2007 and the dry cold season in 2008.

The equipment necessary to carry out the experiment on the field is very modest. It consisted of insemination gun, straws, prospecting gloves, pliers, speculum, thermos, thermometers. For the transport and the packaging of the semen we used a liquid nitrogen container of 35 liters with a conservation capacity of 45 days.

\section{RESULTS}

\subsection{General Aspects}

The difficulties related to equipment are few given the simplicity of the technique. However, it should be noted that failure occurred right at the beginning of the operation. It concerned the loss of liquid nitrogen during air transport between France and Chad. Females for the most part are more than five years old and were bought on the local markets. They were not necessarily a good

Table 1. Flow diagram of the treatments.

\begin{tabular}{|c|c|c|c|c|c|}
\hline \multirow{2}{*}{ Method } & \multicolumn{4}{|c|}{ Products administered } & \multirow{2}{*}{ Insemination } \\
\hline & Norgestomet $^{*}$ & Estradiol $^{*}$ & Luprostiol $^{* *}$ & $\mathrm{PMSG}^{* * *}$ & \\
\hline Treatment $\mathrm{PGF}_{2 \alpha}$ & 0 & 0 & $\begin{array}{c}7.5 \mathrm{mg}=\mathrm{D} 0 \\
7.5 \mathrm{mg}=\mathrm{D} 11\end{array}$ & 0 & D14 and D15 \\
\hline Treatment implant & $\begin{array}{c}3 \mathrm{mg} \text { implant }=\mathrm{D} 0 \\
3 \mathrm{mg} \text { injection }=\mathrm{D} 0\end{array}$ & $3.8 \mathrm{mg}=\mathrm{D} 0$ & $7.5 \mathrm{mg}=\mathrm{D} 8$ & $500 \mathrm{IU}=\mathrm{D} 10$ & D12 and D13 \\
\hline
\end{tabular}

${ }^{*}$ Crestar Syncromate-B ${ }^{\circledR}$, N.D., Intervet, D0 = first day; D15 $=15^{\text {th }}$ day; ${ }^{* *}$ Prosolvin ${ }^{\circledR}$, N.D., Intervet; ${ }^{* * *}$ Syncro-Part. 
herd for synchronization action. Herd management entrusted to a not experienced employee was out of control during the operation: bad driving grazing animals, removal of implants from suckling cows and refusal to castrate the young males of the herd.

\subsection{Synchronization of Estrus}

With $\mathrm{PGF}_{2 \alpha}$ alone, 130 of 170 females came into heat at 14 days that is $76.47 \%$. The criteria retained for the evaluation of heats were coupling simulation, internal signs (vaginal mucus discharge and opening of the cervix) observed using a speculum.

Females treated with the combination of four hormones showed signs of heat at $58.33 \%$ that is 70 cows out of 120 . Thirty animals lost their implants in the early days of the operation and are from the group of $50 \mathrm{fe}-$ males that showed no signs of heat. The true rate would have been $77.77 \%$ for this group.

\subsection{Pregnancy Rate}

For the two operations, the overall pregnancy rate was $37.93 \%$. This rate varies from $29.41 \%$ for the method using a single hormone to $50 \%$ for the method involving four hormones used in combination or a true rate of $66.66 \%$ percent if females that have lost their implants are not taken into account (Table 2).

\subsection{Survival of Crossbreeding Products}

Survival rates were generally low for the two years. Two third of products issued from crossbreeding have not reached the age of weaning. Survival rates are $40 \%$ in 2007 and $33.33 \%$ in 2008 that makes an average of $36 \%$.

\section{DISCUSSION}

The signs of heat were observed in $76.5 \%$ and $77.8 \%$ among the females treated respectively with prostaglandin alone and implants (Norgestomet/Estradiol) combined with $\mathrm{PGF}_{2 \alpha}$ and serum gonadotropin. These two non-significant rates are similar to those of $65 \%$ to $70 \%$ observed in Charolais cows after receiving treatment with implants [4-6]. However, they are lower than those observed in Senegal with the Gobra zebu following treatments with implants, 92.8\% [7] and in Europe with Charolais and Salers treated with prostaglandin: $85.7 \%$ [8]. Rates of $90 \%$ and $100 \%$ were recorded respectively in cycled primiparous cows of N'Dama and Maure zebu breeds [9]. In a four-year study conducted with Fulani zebu in Cameroon [10], also higher rates (76\% to 100\%) were obtained after the contribution from the second year of the PMSG to the association of estradiol and Cronolone. In addition, the existence of undetected silent heat should be considered because several authors have observed it in female of African indigenous breeds [11-14].

The pregnancy rate obtained with these two methods varies from $29.41 \%$ using prostaglandin alone and to $66.6 \%$ in the best cases, with the combination method. On the field and on station, this rate is estimated to be 63.45\% in the Arab zebu under natural conditions, the most important breed of our observations [15]. The numbers of the animals and breeds used are very low to assess the breed effect. Only four cows of M'bororo breed in 2007 and two in 2008 were synchronized.

The rate of $29.41 \%$ obtained after treatment with PGF2 $\alpha$ is lower than most of the results obtained by certain authors [7,9,16-18] in African cattle breeds: Maure zebu (40\%), N’Dama (52.5\%), Gobra zebu (23.8\%), Baoule (57\%), Afrikaner, Brahman, Tswana Tuli zebus (37\%) and Friesian and Ayrshire crosses with indigenous Tanzania short horn zebu (60.2\%). It should be noted that our results were obtained in an unfavorable livestock raising condition. In 2008, six females used in 2007 were eliminated because of infertility problems of which three due to lack of cyclic ovarian activity, one to mummification diagnosed and two to aging. "All comers" females are mostly very old, less fertile than the primiparous cows.

The result of combination of four hormones was better in 2008. This situation can be explained by both the methodology used and the elimination of some breeding females as described above. This rate of $50 \%$ is greater than the observations [10] in Cameroon (26.7\% to 35.3\%) and in Tanzania (37.6\%) [19]. It is comparable to those of in Senegal (55.5\%) [7] but less than those obtained in Iran (55\%) [20] and in Tanzania (69.8\%) [18].

If the two reproductive parameters (rate) are comparable to the results obtained elsewhere, survival of products of crossbreeds to weaning age was particularly low. Only four of the eleven calves produced in two operations have reached the age of eight months. This can be mainly attributed to the lack of adequate housing and poor herd management but also the lack of motivation of the breeder.

Although the primary objective of the breeder was not having dairy strains, the stakes are high on the economic basis. Considering the import prices in 2007/2008 the minimum price for the insemination of one female was 39,550 F CFA for the PGF2 $\alpha$ method alone and 59,200 F CFA francs for the second method. This difference is only about 10,000 F CFA if we consider only the products used for synchronization as shown in Table 3.

The main factors that can reduce this cost are the price of imported semen and to a certain extent the number of females to be synchronized. Using a very small staff has increased the cost of producing a calf operation. It was 
Table 2. Synchronization and success rate.

\begin{tabular}{|c|c|c|c|c|}
\hline Method & Number of female & Synchronization rate (\%) & Calves obtained & Achievement rate (\%) \\
\hline $\mathrm{PGF}_{2 \alpha}$ single (2007) & 170 & 76.47 & 50 & 29.41 \\
\hline $\begin{array}{l}\text { Norgestomet/Estradiol/ } \\
\mathrm{PGF}_{2 \alpha} / \mathrm{PMSG} \text { (2008) }\end{array}$ & $\begin{array}{l}120^{*} \\
90^{* *}\end{array}$ & $\begin{array}{l}58.33 \\
77.77\end{array}$ & 60 & $\begin{array}{c}50 \\
66.66\end{array}$ \\
\hline Total synchronized (2 years) & 290 & 68.96 & 110 & 37.93 \\
\hline
\end{tabular}

*Number includes females who lost implants; ${ }^{* *}$ Females normally treated with implants.

Table 3. Estimated minimum costs of the insemination and production a calf of the two methods (excluding investment).

\begin{tabular}{|c|c|c|}
\hline & 2007 & 2008 \\
\hline Norgestomet/Oestradiol & - & $4850^{1}$ \\
\hline PMSG & - & 9930 \\
\hline $\mathrm{PGF}_{2 \alpha}$ & $5940(2970 \times 2)$ & 2970 \\
\hline Insemination tools & 43 & 43 \\
\hline Semen & $14,800(7400 \times 2)$ & $14,800(7400 \times 2)$ \\
\hline Sub-total & 20,750 & 32,600 \\
\hline Transportation & 18,800 & 26,600 \\
\hline Insemination cost of a female & 39,550 & 59,200 \\
\hline Cost of producing a calf & 134,470 & $\begin{array}{c}118,400 \\
(88,800)\end{array}$ \\
\hline
\end{tabular}

${ }^{1} 1 \mathrm{US} \$=500 \mathrm{~F} \mathrm{CFA}$.

134,470 F CFA francs in 2007 and 118,400 F CFA francs $(88,000 \mathrm{~F}$ CFA or if all three badly treated animals are not taken into account) in 2008.

\section{CONCLUSION}

The systematic practice of artificial insemination after estrus synchronization is a technique that overcomes the problems associated with heat detection. Fertility rates remain mostly in Africa below the natural breeding cases (60\% to $70 \%$ ). The results of these two trials are comparable to those reported on other African cattle breeds. It should be noted that our results were obtained in an unfavorable livestock raising condition. The estimated costs of producing a calf obtained are too high to promote the technique of genetic improvement not well known in Chad. The existence of a support structure (liquid nitrogen) is the main factor for improving its utilization in the suburban cattle production system.

\section{REFERENCES}

[1] Thatcher, W.W., Moreira, F., Pancarci, S.M., Bartolone, J.A. and Santos, J.E. (2002) Strategies to optimize reproductive efficiency by regulation of ovarian function. Domestic Animal Endocrinology, 23, 243-254. http://dx.doi.org/10.1016/S0739-7240(02)00160-1

[2] Cairoli, F., Mollo, A., Veronesi, M.C., Renaville, B., Faustini, M. and Battocchio, M. (2006) Comparison between cloprostenol induced and spontaneous estrus fertility in dairy cows. Reproduction in Domestic Animals, 41, 175179. http://dx.doi.org/10.1111/j.1439-0531.2006.00666.x

[3] Holm, D.E., Thompson, P.N. and Irons, P.C. (2008) The economic effects of an estrus synchronization protocol using prostaglandin in beef heifers. Theriogenology, 70, 1507-1515.

http://dx.doi.org/10.1016/j.theriogenology.2008.06.098

[4] Chupin, D., Petit, M. and Pelot, J. (1976) Induction et synchronisation de l'ovulation chez les femelles de race à viande. Journées d'information ITEB-UNCEIA-INRA Paris.

[5] Petit, M., Deletang, F. and Thibier, M. (1978) Reproductive responses of beef heifers and cows to exogenous progesterone administrated in silastre coil, oestradiol benzoate and pregnant mare serum gonadotropin. Theriogenoly, 9, 161-170.

[6] Mauleon, P., Robert, S.J., Mc En Tee, K. and Aguer, D. (1977) Modifying factor of fertility after different Estrus. Control treatment in beef cattle. I.E.C. Conference Control of Reproduction in the Cow Galway, 27-30 September 1997, 280-283.

[7] Mbaye, M. and Ndiaye, M. (1993) Etude des chaleurs et de la fertilité après un traitement de maîtrise de la reproduction chez la vache zébu Gobra. In: Diop, P.E.H., Ed., Maîtrise de la Reproduction et Amélioration Génétique des Ruminants. Apports des Technologies Nouvelles, 27-37.

[8] Mbaye, M. (1979) Induction et synchronisation chez la femelle allaitante post-partum. Mémoire, UNCEIA, Paris.

[9] Cisse, A.B. (1993) Synchronisation des chaleurs chez les vaches Ndama et zébu Maure avec de la prostaglandine 
F2 $2 \alpha$. In: Diop, P.E.H., Ed., Maîtrise de la Reproduction et Amélioration Génétique des Ruminants. Apports des Technologies Nouvelles, 21-26.

[10] Lhoste, P. and Pierson, J. (1976) L'expérimentation de l'insémination artificielle au Cameroun par importation de semence congelée. II. Essai de synchronisation de l'Estrus sur femelles Zébu. Revue d'Elevage et de Médecine Vétérinaire des Pays Tropicaux, 29, 67-74.

[11] Mbaye, M., Diop, P.E.H. and Ndiaye M. (1989) Etude du cycle sexuel chez la vache de Ndama. In: Atelier sur la Reproduction du Bétail Trypanotolérant en Afrique (FAO-RAF/88/100). Banjul, 34-35.

[12] Mattoni, M., Mukassa-Mugerwa, E., Gecchini, G. and Savoni, S. (1988) The reproductive performance of East African (Bos indicus) zebu cattle in Ethiopia. I. Estrus cycle length, duration, behaviour and ovulation time. Theriogenolgy, 30, 961-971. http://dx.doi.org/10.1016/S0093-691X(88)80059-1

[13] Ralambofiringa, B. (1978) Notes sur les manifestations du cycle oestral sur la reproduction des femelles Ndama. Revue d'Elevage et de Médecine Vétérinaire des Pays Tropicaux, 31, 91-94.

[14] Traore, A. and Bako, G. (1984) Etude du cycle sexuel chez les vaches et génisses NDama élevées au C.R.Z. de Sotuba. Revue d'Elevage et de Médecine Vétérinaire des Pays Tropicaux, 37, 485-487.
[15] Zeuh, V. (1992) Aperçu sur les ressources animales du Tchad, Bovins, Ovins, Caprins, Porcins et Camelins. LRVZ/Farcha, N'Djamena, Tchad, 13 p.

[16] Buck, N.G., Light, D. and Makabo, A.D. (1983) Conception rates of beef cattle in Botswana following synchronisation of oestrous with closprosteneol. Animal Production, 80, 61-67.

[17] Ouedraogo, A. (1989) Contribution à l'étude de la synchronisation des chaleurs chez la femelle Baoulé au Burkina Faso. Thesis, EISMV No. 4, Dakar, Senegal.

[18] Mgongo, F.O.K., Mujuni, P. and Kitambi, A. (2009) Pregnancy rates of crossbred dairy cattle synchronized using $\mathrm{GnRH}$ and one injection of PGF2alpha versus two injections of PGF2alpha prior to insemination. Livestock Research for Rural Development, 21, 136. http://www.lrrd.org/lrrd21/8/mgon21136.htm

[19] Schmidt, H., Jochle, W. and Smidt, D. (1973) Oestrous cycle synchronisation and oestrous induction in indigenous and European cattle in Tanzania. Journal of Agricultural Science, 81, 381-389.

[20] Zare Shahneh, A., Mohammadi, Z., Fazeli, H., Moradi Shahre, M. and Dirandeh, E. (2008) The effect of GnRH injection on plasma concentrations, conception rate and ovulation rate in Iranian cows. Journal of Animal and Veterinary Advances, 5, 1137-1141. 